\title{
THE ASPECTS OF TRADITION AND MODERNITY IN CHAIM POTOK'S NOVEL, IN THE CHOSEN
}

\author{
Noémi Vanderstein \\ Ph.D. Student, Jewish Theological Seminary - University of Jewish Studies
}

\section{SUMMARY}

Tradition and modernity are two expressions living together and living in conflict with each other, as well. Every human being has to face the choice between these elements because people are born into a world full of traditions of their families, however, they live in communities confronting new challenges.

Next to real life, the topic of the duel between tradition and modernity appears in literature, too. I introduce Chaim Potok's novel, The Chosen from the point of view of the main characters' struggle. Danny and Reuven live in Jewish families according to strict rules, and they watch the outside universe with curious eyes hoping that both of them are able to stand the proof.

\section{INTRODUCTION}

The topic of this paper is a pair of oppositions. I focus on two important expressions in the way of losing something. Human beings make a struggle between tradition and modernity, and the end of this struggle is either losing traditions that involves winning modernity or losing modernity that means winning traditions.

I believe that in the centre of the novel of The Chosen by Chaim Potok a challenge stands. The main characters feel that they live their lives according to the ancient religious rules but on the other hand, they realize that the world where they live is the modern America. It suggests that they have to suit to the requirements of tradition and modernity at the same time.

\section{TRADITION}

Applying Chaim Potok's novel, The Chosen I define what the expression of 'tradition' means. First, I intend to make a difference between assimilation and integration.

Assimilation and integration stand in a binary position. In Structuralism, the principle of binary oppositions is the centre of the investigation. The fundamental binarism governs human beings' existence and thoughts; they take on meaning and become cultural signs. (Rabinow P. 1991) 'To assimilate' means "to allow people to become part of another social group or state." (Hornby A. S. and Ruse C. 1990) 'To integrate' means "to join parts into a whole" (Hornby A. S. and Ruse C. 1990) and "to cause people to be together as one group." (Hornby A. S. and Ruse C. 1990) Modernity involves both these two expressions. Assimilation and integration suggest that human beings lose their identity and profit a new one.

I believe that if you live according to the traditions, you always forgive the faults of your enemies, and you look on everybody as your friend. In order to achieve peace in your soul, you should try to live without hurting anybody.

Born into a Jewish family, I was always interested in Judaism. Nowadays, in the centre of my interest there is the question of how Jews experience their Jewry. Focusing on this topic, I have to distinguish one group of Jews from another. I try to make two categories of Jewish people. Orthodox and Hasidic people are those who live their lives according to the rules and teachings of the Torah. Neologism is the other trend. The people in this group also believe in the words of the Torah but put the emphasis on their living, and the importance of religion comes only after that. Both of these communities live in the world of traditions. 
The man is different from animals in two significant fields. One of these fields is that man is open to the world, so he is able to receive from and give information to other individuals; and the other scope is language that people use. Language is the tool for people to accomplish their openness. According to Wolfhart Pannenberg, "man's ambition goes over everything that appears in front of him and there is nothing in the world to give satisfaction to him." (Pannenberg W. 1998)

\section{MODERNITY}

My aim is to examine the realization of the power of man as a Subject open to the world. To show the task of existence and fantasy in people's lives, I use Chaim Potok's novel, The Chosen.

Since man has the ability of openness to the world, he is influenced by surrounding effects. First, he needs to enquire about them. Later, he accepts and gets, and he even alters them. This process is similar to the children's acquaintance of the world. A new-born baby is not capable to orient himself, he only knows his environment in the way he learns it. As the baby is growing, he uses more and more sense organs and he has the ability of getting more and more knowledge.

People have pretensions that cannot be fulfilled by language or culture so they have to use one of their talents called fantasy. Fantasy goes beyond the task of existence. When people use their fantasy, they create something new for the world. Creativity plays an important role in human beings' thinking. Since people have different thoughts and experience of the world and of reality, their creativity and fantasy also differ.

What is fantasy? Attila Attila Kiss argues that "Recent poststructuralist attempts to define the fantastic have shared the common goal of moving beyond the methodological limits of genre categorization in order to reveal the logic of the fantastic as an effect which emerges in the speaking subject and as a general operation that is always at work in the symbolizing social practices of culture." (Kiss A. A. 2002) He adds that the representations of the fantastic have effects on the "psycho-somatic heterogeneity of the subject." (Kiss A. A. 2002) He also suggests that "The various perspectives that have been offered by the recent psychoanalytically informed theorization of the fantastic all seem to relate the fantastic not only to a subversive operation, but also to a quest, an attempt to reach a totality which has been lost or which always appears to be beyond our reach. ... This quest in culture is parallel with the quest inside the subject that aims at compensating for the losses (of the mother's body, of reality) and the split that constitutes the subject. In this respect, the fantastic is an intensification of that compensatory mechanism which is constitutive of all signification." (Kiss A. A. 2002)

I agree with Katalin Gellér in the fact that the basis of the fantasy is "emigration from the present." (Gellér K. 2002) When we get out of our situation, we are able to get into another one. As Pannenberg says "getting out of our position involves creating a movement of productivity." (Pannenberg W. 1998) I claim that when we use our fantasy and creativity, we heavily rely on our memories and discover the new at the same time.

\section{CONFLICT BETWEEN THE OLD AND THE NEW}

All of the main characters in the novel of The Chosen are human beings knowing a lot of things about the world but they are not satisfied with their knowledge. They want to know more, they want to go beyond existence, and want to interfere in their heritage. According to this concept, their lives are connected by creativity and fantasy. They cannot imagine what happens to the man being grown up in another way. 
I argue that every realization and perception start with a coming thought. In this sense, Potok is the initiator of discovering a new perspective of Freudianism. On the other hand, Reuven is partner in Potok's work and he opens the way for Danny to find a new objective. I claim that both characters play a very important role in going beyond the existence and in examining the state of the soul by the works of Freud.

When man thinks of something - especially for a so far unknown thing - he has an idea of that object. He uses his fantasy to create rules and theories on that subject but he has to prove his thoughts. In Potok's novel, in The Chosen the author wants to get answers to the following elements of ongoing tension: "I don't need the outside world to solve my problems. It is disgusting and creates only ugliness. Why do I need the noise, the music, the pornography, and the heathenism therein. Using my own inner resources I can solve all my problems from inside my own tradition. There are some really beautiful things in the world beyond us. There are really things that we can learn from the world. Not everything about the outside world is ugly. Let's borrow the good things, and, by integrating them with our tradition, enrich ourselves as a result." (Potok C.: Lecture, 1986)

These two elements - tradition and modernity - suggest that there is a struggle in every human being. On one hand, people believe that they are the only one who can solve their problems and they do not rely on the outside world since it is a disgusting thing. Contrary to this opinion, there is the second element. It says that human beings are open to the world. The outside world is not full of ugliness and it suggests that we have the chance to adopt the good things. The profit of this integration is enriching our tradition and enriching ourselves, as well.

The reader can realize in The Chosen that these two elements are in confrontation with each other. The story itself is about Jewish world and Jewish traditions. I have to say that this world is the basis of the above mentioned tension.

Danny is in the middle of the struggle between these two elements of the tension. He lives in a Hasidic Jewish family with strict rules. It implies that the Hasidic community lives their lives according to the old traditions written down in the holy books of the Torah. It also suggests that this group of people does not accept any new information coming from the outside world because all of the things that are not in the history of the Hasidic people are wrong and usefulness.

On the other hand, Danny is a young boy with full of curiosity towards the world. He wants to get to know the nice and beautiful side of the outside world. $\mathrm{He}$ is in a desperate situation because he does not want to lose his past and his identity, however, he also seeks for something that can solve his problems. His problems originate from the world, from the culture where he lives in.

He finds a solution to his situation. He starts to read and analyze Freud's psychoanalytic theory. It is interesting for me that a Jewish young boy, who is grown up according to the ancient rules, finds peace in his soul when he starts to know the work of a modern psychologist.

Reading Freud's works starts not long after the accident of Reuven or at least not long after the development of the teenagers' friendship. All of Potok's questions are answered by the end of the story. A new way of upbringing and a new way of education comes to the scene, it exists as the starting point of the whole process. I claim that this influence is impaired and increased by the world-condition itself. Danny's main problem is that his father rears him in silence. Reb Saunders speaks to his son only in front of the Hasidic community when they talk about religious rules.

It is really difficult to learn from somebody - even if he is your father - who does not speak to you and who wants to raise you with the technique of silence. This problematic circumstance leads Danny going to the library where he meets Reuven's father. Since Danny 
is a clever boy with brilliant mind, Reuven's father gives him numerous amounts of books to read. He also gives a gift to Danny. This gift is not simple a gift but a difficulty, too.

It is a gift or - I have to say - it is a profit to Danny. Why? In hard conditions, Danny meets Freud who has no supernatural, no priest and no rabbi. Most of our actions come from the unconscious, come from inside ourselves about which most of us are only dimly aware. (Potok C.: Lecture, 1986)

It is also a difficulty - or I have to say - it is a loss for Danny. Why? Freud's thoughts are not easy to be connected to the religious beliefs. Jewish mentality does not cope with the unconscious. Chaim Potok raises a question: "How do you relate this kind of a system to a religious world?" (Potok C.: Lecture, 1986)

I agree with the opinion of Potok as he answers the above asked question: "Danny Saunders comes to this realization in ironic fashion in The Chosen. Caught in the throes of a strange method by which his father is teaching him compassion for human suffering. Danny finds in Freud the instrumentality for handling this pain and suffering." (Potok C.: Lecture, 1986)

\section{CONCLUSION}

All of the characters in the novel of Chaim Potok, in The Chosen live in an existing world. There are a lot of known things around them but - since they are human beings - they are born with the ability of getting to know the unfamiliar. The characters have their culture and their language as a tool in their hands to establish the truth in a question that goes beyond existence and goes beyond reality.

I claim that people exist because God want them to live. God gives them the ability to think and to think even beyond existence. People use their fantasies and creativities in building up theories but the thoughts are limited. Man's thinking cannot go over death because the only creator who knows whether death is the end or the beginning of life is God.

In man's openness to the world, fantasy is a very determining factor. It has the power of creation and the desire of reaching new perspectives. Fantasy, together with creativity, goes beyond existence and looks for the non-exists. As in the sense of Freudianism, fantasy can be used through language. Language is the medium through people express their thoughts and feelings, and through the task of existence is fulfilled.

As a conclusion, I argue that man is open to the world and he constantly uses his fantasy as a compensation of losses. Human beings - living in their culture - use their language to go beyond existence, and use their fantasy to raise questions that need to be answered.

Tradition and modernity give a chance for human beings to choose. If the individual chooses tradition, he profits it and loses modernity. If the individual chooses modernity, he wins it and loses tradition. I believe that tradition and modernity live together in our lives but human beings are not able to suit to both of them at the same time.

\section{BIBLIOGRAPHY}

Hornby, A. S. and Christina Ruse. Oxford Student's Dictionary of Current English. Budapest: Akadámiai Kiadó and Oxford University Press, 1990. p. 37., 334.

Kiss, Attila Attila et al., eds. The Iconography of the Fantastic. Eastern and Western Traditions of European Iconography 2. Szeged: JATEPress, 2002.

---- The Iconography of the Fantastic. Eastern and Western Traditions of European Iconography 2. Attila Attila Kiss. "The Iconography of the Fantastic: An Introduction." Szeged: JATEPress, 2002. p. 22-23.

-.-. The Iconography of the Fantastic. Eastern and Western Traditions of European Iconography 2. Katalin Gellér. "Figures of Fantasy." Szeged: JATEPress, 2002. p. 299. 
Pannenberg, Wolfhart. Mi az ember? [What is man?] Budapest: Egyházfórum, 1998.

p. 16., 23.

Potok, Chaim. "The Chosen." Chaim Potok lecture (1986).

Available: http://www.lasierra.edu/-ballen/potok/Potok.unique.html.

Access: 24 January 2007.

---- The Chosen. New York: The Random House Publishing Group, 2004.

Rabinow, Paul ed. The Foucault Reader. An Introduction to Foucault's Thought. London:

Penguin Books, 1991. p. 51-75. 